\title{
ONE PERSON'S IMPACT ON ARCHAEOLOGY
}

\section{A} sked to identify those individuals whose contributions to the archaeology of Latin America have been of long-lasting significance, each of us would come up with a list of colleagues whose fieldwork, publications, and cadre of students would be the singularly impressive sort of stuff that is, or has been until now, recorded in American Antiquity obituaries. There are, however, contributors of true importance whose role in archaeology would never be memorialized in a professional journal; they would, in fact, very probably not even be mentioned in the recently inaugurated SAA Bulletin obituary notices, despite the significance of their work. Just such a person has recently been lost to the world of Maya studies through a tragic accident, and because his impact on archaeology would otherwise go largely unrecognized, the five of us with the longest histories of fieldwork in Belize have joined in the sad task of filling these two pages with the story of who he was and what he did.

Harriot Wentworth Topsey, archaeological commissioner of Belize, born May 22, 1953, was killed on October 9, 1995, when he lost control of his vehicle and it rolled into a drainage ditch. His death robbed his three young sons and one daughter of their father. It also took from the country its first holder of a degree specifically in archaeology, its second Belizean archaeological commissioner, and a person whose valiant and dogged championing of the cause of archaeological and historical preservation has permanently changed the face of archaeological work in the country. It seems ironic that Harriot met his end not on some remote tropical forest track but rather in Belize's capital of Belmopan, at the end of a long evening. We suppose we should say at the outset that Harriot did not fit any standard image of an archaeologist (which, indeed, he was not), of a bureaucrat (which, indeed, he was not), or of the head of an active and growing Department of Archaeology (which he most emphatically was).

Harriot chose archaeology not because digging seemed the kind of work to which he could dedicate his life, but because it was the alternative to a position in the coroner's office. Having decided that he preferred the long-dead to the recently deceased, he became a trainee in the department under Joseph Palacio, the first Belizean commissioner. Before Palacio left office Harriot received a scholarship for study in England, where he received a B.Tech. in archaeological sciences at the University of Bradford in 1979. He returned to Belize later that year to relieve Elizabeth Graham (commissioner 1977-1979) of responsibility for the country's archaeology, and began almost at once to leave his distinctive imprint on his department, where he took great pride in being the youngest department head in the Belizean civil service. He also began to leave his imprint on the country in many nonarchaeological ways, for Harriot was anything but a musty, office-ridden civil servant.

Everyone who remembers Harriot will recall with a peculiar fondness his habitual attire, which was about as nonconformist as clothing can be in any circumstance. One of his enduring values was, in fact, that he made even the scruffiest archaeologists seem well-dressed in comparison. For a high-level discussion he was as likely as not to appear clad in his habitual sandals, cutoffs, and T-shirt, often with some socially unacceptable slogan emblazoned across his chest. He was, furthermore, ever and always a ladies' man. This propensity, coupled with his sartorial statements of independence, his almost determinedly frivolous demeanor, and his love of Caribbean dance music (when he was not parodying

Latin American Antiquity, 6(4), 1995, pp. 291-292.

Copyright $(\mathcal{C} 1995$ by the Society for American Archaeology 
Engelbert Humperdinck or Tom Jones) made it easy to dismiss him as a lightweight shoot-from-the-lip type who could be shouldered aside by any foreign archaeologist with a particular personal agenda to pursue. Those who made that mistake lived to regret it.

Harriot's offbeat manner belied a dogged determination to see Belize's archaeology organized for the good of the entire country, to see his nation's heritage afforded protection that went beyond the already stringent legislation, and to ensure that where profit was to be made, it would fall more to Belizeans than to outsiders. Some foreign archaeologists came to dislike Harriot intensely for his stance on such matters, and a few fought unreasonably to have some of his conditions to the granting of an excavation license rescinded. But Harriot fought back with determination, and usually won. He fought, too, against what he saw as the narrow profit-oriented development views of some of his countrymen; on this battleground, though, where he could not exercise the power of a Belizean over archaeologist guests in his country, his abiding lack of tactical sense often cost him dearly. No better example exists than his attempt to have the mid-nineteenth century Belize City market building, a cast-iron assemble-it-yourself wonder shipped out from England, preserved on its original site. He fought business-backed public opinion, he fought his own ministry, and he did so on fully public open ground. The result was that the market came down, and so did Harriot. While he was out of favor he waged a highly significant and difficult battle against his ministry to prevent commercial salvage of the wrecks that dot Belize's barrier reef, and he lost. It took him some time to make his way back into the corridors of power, but when he did so he began a program of assembling financial support for the preservation of his country's archaeological and historic heritage that we knew would live after him, even when we assumed that he would enjoy a long and fruitful life.

Harriot received a master's degree in 1987 from the University of Calgary, where he enjoyed the tutelage of David Kelley, but in truth his accomplishments include almost none of the stuff of journal obituaries, not even the achievement of the doctorate from Tulane University on which he was at work at the time of his death. They do include, however, an unmistakable love of his country and a keenly honed sense of the need for controlled development of archaeological resources. His concern with educating Belizeans about the richness of their archaeological heritage led him to organize traveling exhibits of artifacts, which ultimately reached even the country's most inaccessible schoolrooms and town halls. Harriot built his monument not out of books and articles and sites but rather out of such public education and out of controls and restrictions and systems, all of which now shape the archaeological work carried out by North Americans and Europeans in Belize. His boundless energy and his clear vision of what he wanted for Belize from archaeology and archaeologists have changed the meaning of Maya research in Belizean eyes. They have also changed the way in which Mayanists who excavate in the country perceive their roles and their responsibilities to the nation that has afforded them a place for their work. Out of these changes has come a new kind of partnership between those who study Belize's archaeological heritage and the government under whose watchful eye they labor. Today's structure, which we thought Harriot would be there to oversee for many years to come, gives archaeology more meaning for both members of the partnership than it had in times past, and we believe that we, as well as Belize, are the better for it.

If Harriot could see our writing efforts now, we are sure he would be convulsed with laughter. Among other things, he would know as well as we do that no words set down upon a page can capture the spirit of the person he was. Pendergast remembers the response of a taxi driver years ago, on hearing Topsey's name: "Ah, dat Topsey, man, he only sweet," which is to say, "He's really something." As a comment on Harriot's ineffable personality, as well as on his lasting gifts to his native land, those words do as well as any.

DAVid M. Pendergast Editor

with Arlen Chase, Diane Chase, Elizabeth Graham, and Norman Hammond 